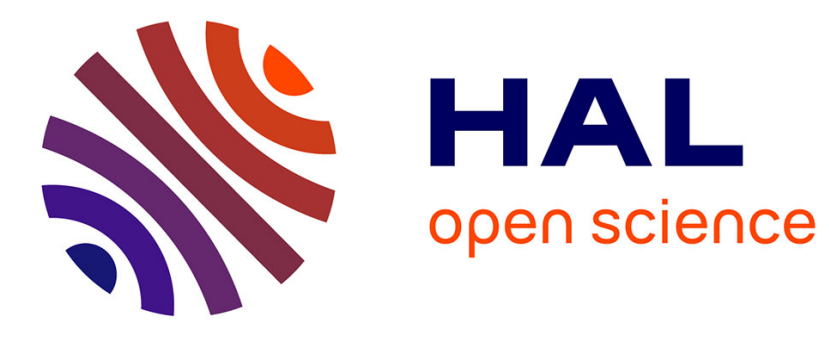

\title{
How is genomics changing cattle breeding?
}

Didier Boichard, Vincent Ducrocq, Pascal Croiseau, Sebastien S. Fritz

\section{To cite this version:}

Didier Boichard, Vincent Ducrocq, Pascal Croiseau, Sebastien S. Fritz. How is genomics changing cattle breeding?. JAM Joint Annual Meeting, Jul 2016, Salt Lake City, United States. hal-02738726

\section{HAL Id: hal-02738726 \\ https://hal.inrae.fr/hal-02738726}

Submitted on 2 Jun 2020

HAL is a multi-disciplinary open access archive for the deposit and dissemination of scientific research documents, whether they are published or not. The documents may come from teaching and research institutions in France or abroad, or from public or private research centers.
L'archive ouverte pluridisciplinaire HAL, est destinée au dépôt et à la diffusion de documents scientifiques de niveau recherche, publiés ou non, émanant des établissements d'enseignement et de recherche français ou étrangers, des laboratoires publics ou privés. 


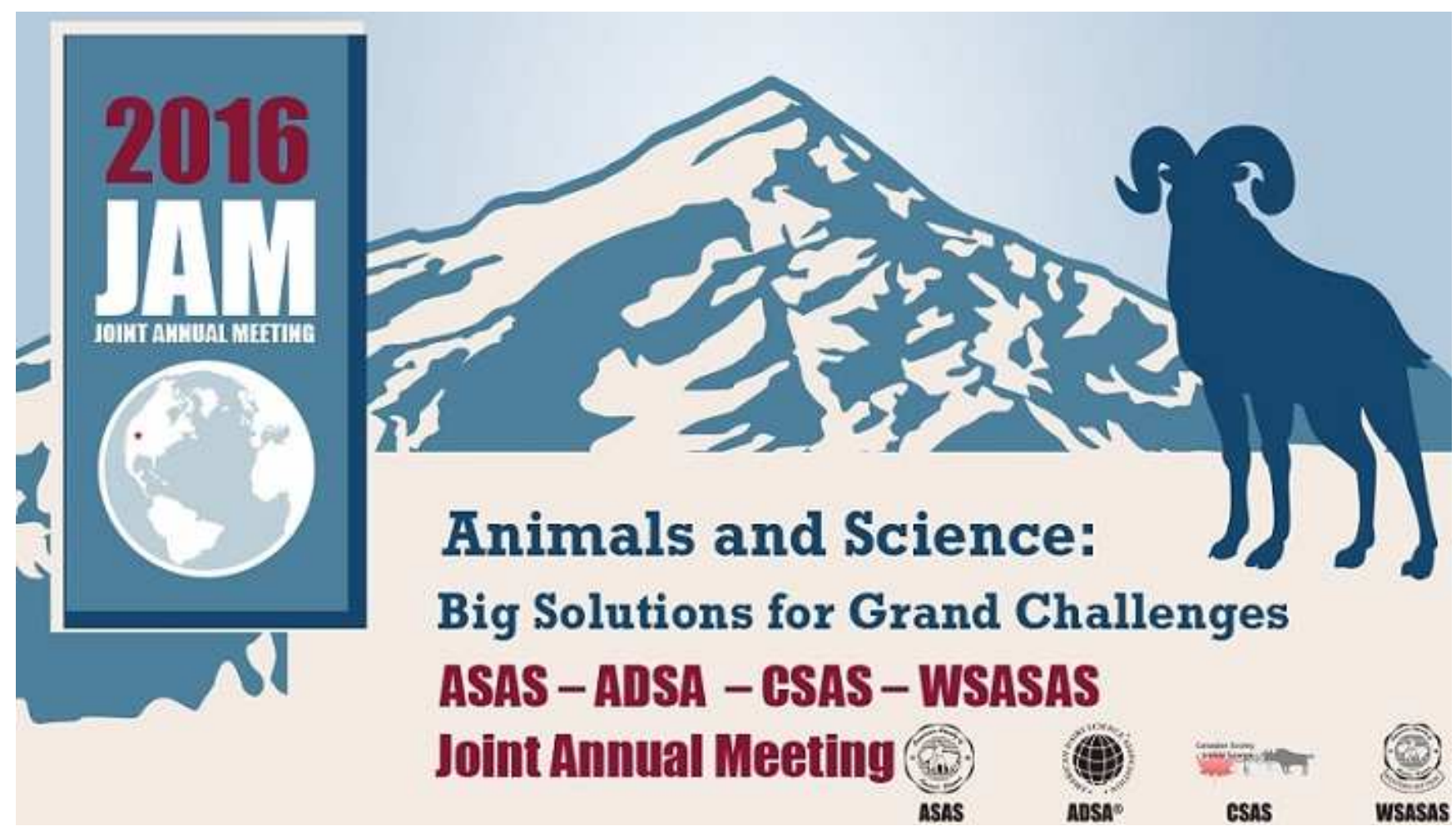

408

How is genomics changing cattle breeding?

Thursday, July 21, 2016: 2:45 PM

Grand Ballroom J (Salt Palace Convention Center)

Didier Boichard, GABI, INRA, AgroParisTech, Universite Paris Saclay, Jouy-en-Josas, France Vincent Ducrocq, GABI, INRA, AgroParisTech, Universite Paris Saclay, Jouy-en-Josas, France Pascal Croiseau, GABI, INRA, AgroParisTech, Universite Paris Saclay, Jouy-en-Josas, France Sebastien Fritz, GABI, INRA, AgroParisTech, Universite Paris Saclay, Jouy-en-Josas, France

Abstract Text: Genomic selection offers considerable flexibility to increase genetic trends in dairy cattle breeding, through a decrease in generation interval, an increase in selection intensity, and an increase in reliability for females and for low heritability traits. It is also an opportunity for more sustainable breeding, in terms of breeding goal and genetic variability. With a shorter generation interval, there is a big risk of increasing inbreeding if semen dissemination policy of elite bulls is not changed. However, using a large number of young bulls both as service bulls and bull sires is a simple solution for both maximizing genetic trend while reducing inbreeding trend. Female genotyping is a key challenge for within herd selection and, simultaneously, for replacing current reference populations based upon progeny tested bulls, assembling new ones in breeds of more limited size, and for selection of newly recorded traits. At a reasonable price and coupled with use of sexed semen, female genotyping is profitable for the farmers and is becoming a routine practice in an increasing number of herds. New applications are generated such as renovated mating plans, efficient management of genetic defects, prediction of cows' future career and optimization of culling policy. With more diverse bulls on the market and with female genotyping, genomic selection also opens new avenues for more customized breeding across herds or production systems. A big challenge is to reduce the dependency of genomic predictions on relationship between candidates and the reference population. A strong effort is presently dedicated to integrating genome sequence information into predictions, in order to improve their accuracy and persistency. To increase the accuracy, within and especially across breeds, causal variants or very close proxies should be identified and included in the predictions, while discarding or limiting the weight of many other variants generating noise. In the longer term, further customization of selection will be possible by accounting for GxE interactions. Important developments are also necessary to decrease loss of favorable alleles through genetic drift.

Keywords: dairy cattle; genomic selection

See more of: EAAP Symposium

See more of: Breeding and Genetics 
Start

Browse by Day

Author Index

\section{Meeting Information}

When:

July $19-23,2016$

Where:

Salt Lake City, UT

Privacy Policy Terms of Use Staff American Society of Animal Science, PO Box 7410, Champaign, IL 61826-7410 E-mail: Rights Reserved. asas@asas.org, Ph. 217.356.9050, Fax 217.689.2436 All pages Copyright @ 2012 ASAS. All 